\title{
The Role of ICT in ASEAN-5's Services Exports: A Panel Study
}

\author{
Beng Ann Tee \\ Universiti Kebangsaan Malaysia \\ Siew Yean Tham ${ }^{b}$ \\ ISEAS-Yusof Ishak Institute \\ Andrew Jia Yi Kam ${ }^{\mathrm{c}}$ \\ Universiti Kebangsaan Malaysia
}

\begin{abstract}
ICT intensive services were found to contribute to the service export growth in developed countries. However, empirical work on the role of ICT in ASEAN's services export is sparse due mainly to the scarcity of bilateral services trade data. This study uses mirror data from the ASEAN-5's trading partners from 2000 to 2012 for examining the impact of ICT on the ASEAN-5's services export. A set of constructed ICT indicators are found to have significant positive network effect on the ASEAN-5's services export. Thus, the higher the ICT development level in both trading partner countries, the higher their bilateral services exports with each other. But, the positive impact of ICT on the ASEAN-5's trade in services can be offset by the presence of trade costs. Therefore, policies enhancing trade facilitation should be used in tandem with the development of ICT in order to promote the ASEAN-5's services export.
\end{abstract}

Keywords: ASEAN, gravity model, ICT development index, services export JEL classification: F1, F14, L8

\section{Introduction}

Since the 1990s, the rapid expansion of trade in services is closely associated with developments in information and communication technology (ICT) $)^{1}$-intensive services such as communication, finance and wholesale trade (Song, 2008). The growth rate for ICT-intensive other commercial services has increased progressively from $32.2 \%$ in 2005

a Institute of Malaysian and International Studies, Universiti Kebangsaan Malaysia, 43600 Bandar Baru Bangi, Selangor, Malaysia. Email: p62918@siswa.ukm.edu.my (Corresponding author)

b ISEAS-Yusof Ishak Institute, 30 Heng Mui Keng Terrace, Singapore 119614. Email: tham_siew_yean@iseas. edu.sg

c Institute of Malaysian and International Studies, Universiti Kebangsaan Malaysia, 43600 Bandar Baru Bangi, Selangor, Malaysia. Email: andrew@ukm.edu.my

* This is a revised version of a paper presented at the 15th East Asian Economic Association International Convention, at Bandung, Indonesia, 5-6 November 2016. The authors would like to thank the discussants for useful comments for revising the paper. The usual caveat remains.

Andrew Kam Jia Yi would like to acknowledge the support from Projek Arus Perdana AP-2017-003/1 grant.

1 ICT refers to technologies that provide access to information through telecommunications. It is the same as information technology (IT), but focuses mostly on communication technologies. This includes the Internet, wireless networks, cell phones, and other mediums of communication (Christensson, 2010).

Article Info: Received 24 March 2019; Revised 21 October 2019; Accepted 21 January 2020

https://doi.org/10.22452/MJES.vol57no1.1 
to $35.0 \%$ of total services trade in 2016 (WTO, 2017). Theoretically, ICT affects trade positively by reducing information costs across international borders (Mattes, Meinen, \& Pavel, 2012). Previous studies have highlighted the importance of ICT in increasing exports through improvements in productivity (Ahmed, 2007; UNCTAD, 2008; World Bank, 2009).

Exports of services from the Association of Southeast Asian Nations (ASEAN) to the world market has increased by more than three times from USD327.5 billion in 2000 to USD1052.1 billion in 2016 (WTO, 2017). ASEAN's imports of services from the world market has also grown significantly with a similar trend as exports, from USD375.9 billion in 2000 to USD1,274.3 billion in 2016. Although, ASEAN's trade in services decreased during the global financial crisis of 2008/09, this has subsequently recovered in each of the ASEAN economies.

This paper analyses the relationship between services trade and the use of ICT in each of the ASEAN-5 (Indonesia, Philippines, Malaysia, Thailand and Singapore) services' trade with key trading partners. It examines the impact of ICT on the ASEAN-5's services export by employing panel data, based on the specifications of a gravity model of oneway bilateral trade flows from 2000 to 2012. The paper is structured as follows. In Section 2, the relevant literature is discussed. The methodology and data are discussed in Section 3 while the gravity model used for estimating the impact of ICT on exports is presented in Section 4. The findings and discussions of the results are provided in Section 5 , followed by the conclusion in Section 6 .

\section{Literature Review}

Numerous studies have discussed the role of ICT in overcoming distance-related trade costs (Ahmed, 2007; Lennon, 2009; Liu, 2011; Yushkova, 2014). These studies indicate that ICT contributes to greater transparency and reduces search, matching and communication costs for buyers. ICT-supported intermediation between buyers and sellers creates an e-marketplace that lowers buyer's costs for acquiring information about seller prices and product offerings. This reduces buyer's search costs, thereby reducing inefficiencies (Shemayev, 2014).

ICT-use also helps to reduce monitoring and management costs for firms. It supports communication at a lower cost as the marginal cost of communicating at any greater distance is essentially zero (Choi, 2010; Shemayev, 2014; Song, 2008). Using ICT in monitoring employees and trading partners also ensures transactions can be performed efficiently through electronic means by the principal, thereby reducing cost (Abeliansky \& Hilbert, 2017). Finally, ICT deployment also brings about organisational changes and digitalisation, leading to a reduction in shipping costs (Yushkova, 2014). Using ICT may reduce transit time and its related transport costs (Ahmed, 2007; Lennon, 2009; Mattes et al., 2012; Yushkova, 2014). A caveat is that sunk costs can only be reduced with a sufficient level of ICT penetration (Liu, 2011).

By factoring ICT into the Cournot competition model, Freund and Weinhold (2004) and Liu (2011) summarised the literature in terms of five predictions on the effect of ICT on bilateral trading. First, an increase in ICT penetration between countries can promote bilateral trading. In general, trade will expand with an increase in the number of firms 
with ICT access. An increase in ICT penetration can also reduce the effect of traditional trade barriers such as common borders and common language on bilateral trading. The Internet effectively aggregates world demand and world supply, and exporting countries gain from access to new markets through a reduction or removal of fixed costs. ICT also reduces the impact of distance ${ }^{2}$ on trading. The influence of ICT is also found to be greater for exports compared to imports. Countries that previously only exported to a small number of countries will experience the greatest increase in trade with ICT. Finally, ICT has lesser impact on trade if both countries have a substantial difference in level of ICT development.

The gravity model ${ }^{3}$ is often used as an instrument to test whether a reduction in trade costs (with the use of ICT) leads to an increase in international trade. There are several studies that apply the gravity model to test the role of ICT in reducing trade costs in goods (Kurihara \& Fukushima, 2013; Mattes et al., 2012), in services trade (Dettmer, 2014; Freund \& Weinhold, 2004; Goswami, Gupta, Mattoo, \& Sáez, 2012; Lee, 2012) or in both (Lennon, 2009; Lennon, Mirza, \& Nicoletti, 2009). In general, these studies find that ICT has a positive impact on bilateral trade, and the impact is greater in services trade compared to goods trade. This is particularly so when ICT enables previously non-tradable services to be tradable, due to the characteristics of some services such as e-banking and e-commerce.

It is also found that the role of ICT appears to be more important for exports from developing economies. The existence of sunk cost results in the concentration of international trade in the control of a small number of developed countries. However, with a reduction in sunk costs through ICT, developing countries are able to participate more in international trade, thus explaining why ICT has a greater marginal effect on developing countries compared to developed countries.

Econometric studies however are constrained by data limitations in measuring the impact of ICT, be it for the case of developing countries (UNCTAD, 2011) or for services trade. Studies from developed countries which usually focus on macro (Freund \& Weinhold, 2004; Mattes et al., 2012; Van der Marel, 2012) and micro analysis (Kotnik \& Hagsten, 2013; Sinkovics \& Sinkovics, 2013) are often supported by sufficient statistical data sets (UNCTAD, 2011). However, most evidence from developing countries are only supported by local case studies due to scarcity of available macro data (Ahmed, 2007; Bankole, Brown, \& Osei-Bryson, 2010). These case studies are also sparse due to the same data problems. Hence, more developing country studies are needed to understand the country specifics that can contribute or constrain their respective trade in services. This study therefore aims to fill the research gap by focusing on the role of ICT in the ASEAN-5's services exports.

2 It should be noted that the effect of distance on trade flows will be reduced if distance mainly influences trade because of imperfect information-induced sunk costs. If distance affects trade because of transport costs, then the effect of ICT (e.g. the Internet) on this relationship is ambiguous.

3 The theory behind the gravity model was developed by Anderson (1979), Anderson and Van Wincoop (2003) and Helpman, Melitz and Rubinstein (2008). Anderson's (1979) model was based on constant elasticity of substitution (CES) and Cobb-Douglas preferences assuming product differentiation by the exporting country. To solve the "border puzzle", Anderson and Van Wincoop (2003) used a CES expenditure system to derive a gravity model. In the model, bilateral trade is determined by relative trade costs. 
In addition, a number of empirical studies demonstrate that transnational networks of ICT promote international trade by addressing various problems associated with contract enforcement and information on trade opportunities (Lee, 2012). Such studies typically focus on potential channels for the network effect of ICT. In this regard, the value of ICT to individual users increases with the extent to which it is used in terms of coverage and intensity on international trade (Choi, 2010; Mattes et al., 2012). Likewise, the value of ICT to individual users also increases with the expansion of business networks (Albuquerque, Loayza, \& Servén, 2005; Greaney, 2005, 2009). There are two dimensions in these effects: the requirement of compatible products to exchange data or information (direct network effects) and the requirement of complementarity between products and services (indirect network effects) (Katz \& Shapiro, 1985; Weitzel, Wendt, von Westarp, \& Konig, 2003). Thus, due to network characteristics, the literature suggest that ICT enhances trade only when both trading partners have a similar level of ICT development (Farahani \& Parvardeb, 2012).

This study further contributes to the literature by constructing an ICT index to test the impact of ICT on the ASEAN-5's services exports. Overall, ICT-related trade studies are relatively scarce, with ICT measures limited to Internet use only (Choi, 2010; Freund \& Weinhold, 2002; Michael, 2011). The relationship between trade and ICT can be viewed from three dimensions: trade in ICT services themselves (e.g., international telephone calls), trade in services with ICT as a critical input (e.g., outsourcing data entry or computer programming services), and ICT as a general facilitator of other types of trade (e.g., a farmer using text messaging to check export prices (Guermazi, 2007). Nevertheless, in 2008, the International Telecommunication Union (ITU) developed an ICT development index (IDI) that seeks to monitor the development of ICT across countries (ITU, 2009). This index greatly expands the measurement of ICT beyond mere Internet usage alone and allows for a deeper analysis on the impact of ICT on trade. This study constructs an ICT index using a methodology that is adapted from the one used in ITU (2009).

\section{The Gravity Equation}

The gravity model of international trade was first used by Tinbergen in 1962. The basic model for trade between two countries ( $i$ and $j$ ) takes the form of:

$$
F_{i j}=G \frac{Y_{i} Y_{j}}{D_{i j}}
$$

where $F_{i j}$ denotes the value of country $i$ exports to country $j$; $Y_{i} Y_{j}$ is the mass (or gross domestic product (GDP)) of both country $i$ and country $j$ and as a proxy for market size; $D_{i j}$ indicates the distance between country $i$ and country $j$ to capture trade costs; $G$ is a constant. The GDP of the exporting country measures production capacity of the country, while importer GDP measures demand capacity. The distance between countries is used as a proxy for transportation costs.

Estimation of the standard gravity model of equation (1) in the form of log specifications is as follows: 


$$
\ln \left(F_{i j}\right)=\delta_{0}+\delta_{1} \ln Y_{i}+\delta_{2} \ln Y_{j}-\delta_{3} \ln D_{i j}+\sigma
$$

Generally, the gravity model in international trade studies examines potential barriers and trade determinants (Helpman et al., 2008). However, gravity models are more commonly used in the analysis of merchandise trade than trade services. Among the studies that successfully implemented the gravity model in the service trade are Grünfeld and Moxnes (2003) and Kimura and Lee (2006). Walsh (2006) also supported the suitability of the gravity model as a model for examining services trade as his research findings showed that it is not much different from the results of the study on trade in goods.

It is also very common in many studies to augment the gravity model by including additional "non-physical distance" that affects trade. For example, cultural "distance" inter alia proxy by language barriers, colonial history, etc. are commonly used to explain transaction costs. In this study, the language variable will be used. We postulate that when trading partners use the same language, information loss or friction is low, thereby reducing the search cost in trade (Lendle, Olarreaga, Schropp, \& Vézina, 2016).

Adapting from Mattes et al. (2012), we include a variable called ICT development into the gravity equation. The variable is created to take into account the ICT development of both the importer and exporter. This is to enable us to test the hypothesis that ICT enhances trade only when both countries have good levels of ICT development. The variable is constructed as follows:

$$
\mathrm{ICT}_{i j}=\mathrm{ICT}_{i} \times \mathrm{ICT}_{j}
$$

where $\mathrm{ICT}_{i j}$ is constructed as an interaction term between the selected ICT indicator for country $i\left(\mathrm{ICT}_{i}\right)$ and country $j\left(\mathrm{ICT}_{j}\right)$. It is an interaction term that measures ICT development of both countries. The literature review also points to the importance of accounting for transnational networks of ICT. Therefore, we use a new variable to control the impact of business network in international trade between two countries. We apply Lee's (2012) method that uses bilateral FDI (foreign direct investment) flows between two countries to proxy for the effects of business development networks. The specification is constructed as follows:

$$
\mathrm{FDI}_{i j}=\mathrm{FDI}_{i} \times \mathrm{FDI}_{j}
$$

$\mathrm{FDI}_{i j}$ is constructed as an interaction term between FDIs in country $i\left(\mathrm{FDI}_{i}\right)$ and country $j\left(\mathrm{FDI}_{j}\right)$. Hereafter, equations (3) and (4) will be known as "network effect" where the impact of ICT on trade in services is actually the impact of "ICT network" on trade. The FDI indicator follows a similar explanation. Hence, the full model specification is as follows:

$$
\ln \left(X_{i j t}\right)=\beta_{0}+\beta_{1} \operatorname{lnGDP} i j t+\beta_{2} \operatorname{lnDist} i j+\beta_{3} L_{i j}+\beta_{4} \operatorname{lnFDI} i j t-1+\beta_{5} \operatorname{lnICT}_{i j t-1}+\varepsilon
$$

$X: \quad$ Bilateral service export (mirror import)

GDP: GDP (constant 2005 US\$)

Dist: Geographical distance - latitudes and longitudes of the most important cities/ agglomerations based on population 
LG: Common spoken language - Common spoken language - dummy variable (0 or 1$)$ that a pair of people at random from the two countries uses the same language

FDI: Foreign direct investment, net inflows (current US\$), from equation (4)

ICT: ICT indicators, from equation (3)

$i$ : $\quad$ Exporting country

j: Importing country

$t: \quad$ Years (2000-2012)

where $X$ refers to one-way bilateral service export ${ }^{4}$; $\operatorname{lnGDP}_{i j}$ corresponds to the log of the product of real GDP of both country $i$ and country $j$ (multiplied GDP from both countries); InDist ${ }_{i j}$ refers to the log of distance between countries $i$ and $j$ which proxies trade costs between them; $L_{i j}$ refers to a common spoken language - dummy variable ( 0 or 1 ) that a pair of people at random from the two countries uses the same language; $\operatorname{InFDI}{ }_{i j}$ and $\operatorname{InICT}$ are the network effects explained in equations 2 and 3. To alleviate endogeneity issues between FDI and exports, and ICT development and exports, lagged values of these variables are used in our model. Note that the models are estimated with cluster-robust standard errors to remove the presence of heteroskedasticity.

\section{Data and Estimation}

To achieve the objective of this paper, our gravity equation uses the ASEAN-5's one-way bilateral trade partners' import of services data as the export of services (also known as mirror data). ${ }^{5}$ Although this method of data collection has its constraints, it is the only source of one-way bilateral data on ASEAN-5's exports of services known, at the time of study. The data set, which covers 41 countries $^{6}$ for the period from 2000 to 2012 was drawn from the Trade Map, International Trade Centre (ITC, 2017), foreign direct investment (FDI), GDP and school enrolment, secondary and tertiary data are taken from the World Development Indicators (World Bank, 2017). The physical distance data were from Centre D'Etudes Prospectives et D'Informations Internationales (CEPII) (Mayer \& Zignago, 2011), common spoken language data were from Central Intelligence Agency (CIA) World Factbook (CIA, 2017), and the ICT indicator data from the World Telecommunication/ICT Indicators database (ITU, 2012). For further details, refer to Tables 1 and 2. The equation uses pooled panel data estimation. The selected number of variables in ICT are regressed separately in order to avoid multicollinearity problems. This is to identify the important individual ICT variables that have a significant impact on trade in services of the ASEAN-5.

4 There are cases where countries do not trade with each other. To account for such cases, we add a constant value of 1 dollar to accommodate the natural log specification of the model.

5 Services export data from the Trade in Value Added (TiVA) database are used to do the robustness test for the same model. The data set covers 38 countries for the period from 2000 to 2011.

6 Australia, Austria, Azerbaijan, Belgium, Bulgaria, Belarus, Canada, China, Cyprus, Czech Republic, Germany, Denmark, Spain, Estonia, Finland, France, United Kingdom, Greece, Hong Kong, China, Croatia, Hungary, Ireland, Iceland, Italy, Japan, Korea, Republic of, Lithuania, Luxembourg, Latvia, Malta, Netherlands, Pakistan, Poland, Romania, Russian Federation, Singapore, Slovakia, Slovenia, Sweden, Tunisia, United States of America. 
Table 1. Variable description and sources

\begin{tabular}{|c|c|c|}
\hline Variable & Definition & Source \\
\hline $\begin{array}{l}\text { Bilateral } \\
\text { service } \\
\text { export } \\
\text { (mirror data) }\end{array}$ & $\begin{array}{l}\text { Trade in services data on Trade Map refers to transactions } \\
\text { between residents and non-residents of the compiling economy, } \\
\text { as recorded within the balance of payment (BoP). Bilateral service } \\
\text { export for } 5 \text { ASEAN countries is mirror import from their trading } \\
\text { partners. Based on Trade Map, services are aggregated into } 12 \\
\text { main categories split into several hierarchical levels: } 2 \text { new } \\
\text { categories have been introduced ('manufacturing services on } \\
\text { physical inputs owned by others' and 'maintenance and repair } \\
\text { services'). Merchanting is excluded from trade in services statistics } \\
\text { and 'communication services' and 'computer and information } \\
\text { services' have been merged into } 1 \text { category ('telecommunications, } \\
\text { computer and information services'). }\end{array}$ & $\begin{array}{l}\text { ITC } \\
\text { Trade Map }\end{array}$ \\
\hline $\begin{array}{l}\text { GDP } \\
\text { (constant } \\
2005 \text { US\$) }\end{array}$ & $\begin{array}{l}\text { GDP at purchaser's prices is the sum of gross value added by all } \\
\text { resident producers in the economy plus any product taxes and } \\
\text { minus any subsidies not included in the value of the products. } \\
\text { It is calculated without making deductions for depreciation of } \\
\text { fabricated assets or for depletion and degradation of natural } \\
\text { resources. Data are in constant } 2005 \text { US dollars. Dollar figures for } \\
\text { GDP are converted from domestic currencies using } 2000 \text { official } \\
\text { exchange rates. For a few countries where the official exchange } \\
\text { rate does not reflect the rate effectively applied to actual foreign } \\
\text { exchange transactions, an alternative conversion factor is used. }\end{array}$ & $\begin{array}{l}\text { The World } \\
\text { Bank's World } \\
\text { Development } \\
\text { Indicators } \\
\text { database }\end{array}$ \\
\hline $\begin{array}{l}\text { Geodesic } \\
\text { distances }\end{array}$ & $\begin{array}{l}\text { Geodesic distances are calculated following the great circle } \\
\text { formula, which uses latitudes and longitudes of the most } \\
\text { important cities/agglomerations (in terms of population). }\end{array}$ & $\begin{array}{l}\text { CEPII dataset } \\
\text { (geo_cepii) }\end{array}$ \\
\hline $\begin{array}{l}\text { Common } \\
\text { spoken } \\
\text { language }\end{array}$ & $\begin{array}{l}\text { Dummy variable of } 0 \text { or } 1 \text { that a pair of people at random from } \\
\text { the two countries understands one another in some language. }\end{array}$ & $\begin{array}{l}\text { ClA World } \\
\text { Factbook }\end{array}$ \\
\hline $\begin{array}{l}\text { Foreign } \\
\text { direct } \\
\text { investment, } \\
\text { net inflows } \\
\text { (BoP, current } \\
\text { US\$) }\end{array}$ & $\begin{array}{l}\text { Foreign direct investment are the net inflows of investment to } \\
\text { acquire a lasting management interest ( } 10 \% \text { or more of voting } \\
\text { stock) in an enterprise operating in an economy other than that } \\
\text { of the investor. It is the sum of equity capital, reinvestment of } \\
\text { earnings, other long-term capital, and short-term capital as shown } \\
\text { in the balance of payments. This series shows net inflows (new } \\
\text { investment inflows less disinvestment) in the reporting economy } \\
\text { from foreign investors. Data are in current US dollars. This series } \\
\text { shows net inflows in the reporting economy and it is lagged by } \\
1 \text { year. }\end{array}$ & $\begin{array}{l}\text { The World } \\
\text { Bank's World } \\
\text { Development } \\
\text { Indicators } \\
\text { database }\end{array}$ \\
\hline $\begin{array}{l}\text { ICT } \\
\text { indicators }\end{array}$ & (Refer to Table 2) & \\
\hline
\end{tabular}


Table 1. Continued

\begin{tabular}{|c|c|c|}
\hline Variable & Definition & Source \\
\hline $\begin{array}{l}\text { (Robustness } \\
\text { test) } \\
\text { Bilateral } \\
\text { service } \\
\text { export }\end{array}$ & $\begin{array}{l}\text { Gross exports (EXGR) data come from the row sum of the inter- } \\
\text { national trade flows in the Organisation for Economic Co-operation } \\
\text { and Development (OECD) Inter-Country Input-Output (ICIO) tables. } \\
\text { They are consistent with official (SNA93) National Accounts } \\
\text { estimates of total exports and imports of goods and services, } \\
\text { adjusted for re-exports, as well as estimates for GDP. However, } \\
\text { while National Accounts exports are valued at purchaser's prices, } \\
\text { gross exports for Trade in Value Added (TiVA) indicators are valued } \\
\text { at basic prices in line with the valuation used throughout the ICIO } \\
\text { tables. When transforming exports from purchaser's prices to basic } \\
\text { prices, one of the main adjustments is the reallocation of the } \\
\text { domestic distribution margins (inherent in exports of goods at } \\
\text { purchaser's prices) to exports of services (wholesale, retail and } \\
\text { transportation). A consequence is that, for many countries, total } \\
\text { exports of services in the TiVA database may be significantly higher } \\
\text { than total exports of services reported in National Accounts (and } \\
\text { balance of payments) statistics. }\end{array}$ & $\begin{array}{l}\text { TiVA } \\
\text { database, } \\
\text { OECD }\end{array}$ \\
\hline
\end{tabular}

Source: World Bank (2017), Mayer \& Zignago (2011), CIA (2017).

\subsection{Data on ICT Development}

To obtain ICT indicators, ITU (2016) proposed a combination of a set of sub-indexes to measure three ICT components, namely ICT access, ICT use and ICT skills. These three ICT components are then aggregated to obtain the overall ICT indicator, or the IDI, which is explained in a later section in this paper.

For the ICT development indicators, we refer to the IDI from the ITU at the national level. The IDI is a comprehensive index, aggregating 11 indicators into one index that is used to benchmark and monitor developments in ICT across countries. The IDI, developed by the ITU in 2009, aims to track the digital divide and to measure countries' progress towards becoming information societies. It also gives an indication of the extent to which countries have advanced in the area of ICT development (ITU, 2009). A country's ICT development can be explained in three stages:

Stage 1: ICT access reflecting the level of networked infrastructure and access to ICT

Stage 2: ICT intensity reflecting the level of use of ICT in the society

Stage 3: ICT impact reflecting the result/outcome of efficient and effective ICT use

Moving through these stages depends on a combination of three components: (1) the availability of ICT infrastructure and access, (2) a high level of ICT usage, and

(3) the capability to use ICT effectively. To capture all the three components, the 
construction of a composite index such as the IDI is required. ITU (2009) suggested that the construction of the IDI be further divided into three sub-indices. The following are the only ones used for this study. Detailed explanation of the indicators is given in Table 2:

1. The "access" sub-index captures ICT access and includes infrastructure and access indicators. ICT access is measured by fixed telephone subscriptions per 100 inhabitants, mobile cellular subscriptions per 100 inhabitants and international Internet bandwidth per Internet user.

2. The "use" sub-index captures ICT intensity and includes ICT intensity and usage indicators. ICT use is measured by percentage of individuals using the Internet and fixed (wired) broadband Internet subscriptions per 100 inhabitants.

3. The "skills" sub-index captures ICT capability or skills as indispensable input indicators. ICT skills are approximated by secondary gross ratio and tertiary gross enrolment ratio.

As the ITU indicator is not available for the full period of this study (2000-2012), the construction of the index is replicated based on the underlying data for which information over the relevant time period is available. ${ }^{7}$ Additionally, since many countries already have high literacy rates, the literature suggests that this element can be omitted from the present study (Nath \& Liu, 2016; Mattes et al., 2012).

All sub-indices (ICT access, ICT use, ICT skills) are computed by summing up the weighted values of the indicators included in the respective subgroup. The indicators included in each sub-index are given equal weights. Based on Table 2, the items are normalised using the reference values ${ }^{8}$ in Table 3 . We follow this method as it is also applied by ITU (2009). Subsequently, the overall value of each sub-indices (ICT access, ICT use, ICT skills) is calculated by taking the simple average of the items. Finally, to aggregate the ICT sub-indices into one index, we use the weighting system (generated using the principal component analysis (PCA) method) from ITU (2009). PCA identifies the relative importance of the indicators selected in each subgroup. It assigns a relative weight to each indicator, ICT access and ICT use are each given a $40 \%$ weightage while the ICT skills sub-index weightage is set at $20 \%$.

7 There are four elements that will be removed in the study. These are: households with a computer, households with Internet access at home, mobile broadband subscribers per 100 inhabitants and adult literacy rate. The data for the first three indicators are not available for the required time period and countries and are thus omitted from the present study.

8 For the IDI, the distance to a reference measure is used as the normalisation method. The reference measure is the ideal value that could be reached for each variable (similar to a goalpost). In all of the indicators chosen, this will be 100, except for two indicators: international Internet bandwidth per Internet user, which in 2000-2011 ranges from 42.88 (bit/s/user) to more than 964,620. To diminish the effect of the large number of outliers at the high end of the value scale, the data are first transformed to a logarithmic (log) scale. The ideal value is then computed by adding two standard deviations to the mean of the rescaled values, resulting in a log value of 5. Mobile cellular subscriptions, which in 2000-2011 range from 0.21 to 209.64 (per 100 inhabitants). The ideal value is computed using the same methodology used for the bandwidth data, by adding two standard deviations to the mean. The resulting reference value is 93-175 subscriptions per 100 inhabitants (ITU 2009). 
Table 2. Construction of the IDI index

\begin{tabular}{cc}
\hline Sub-Indices $(A),(B)$ and $(C)$ & $\begin{array}{c}\text { Formula } \\
\text { normalised }(x)\end{array}$
\end{tabular}

ICT access (A)

Fixed telephone lines per 100 inhabitants $\left(a_{t}\right)$

Mobile cellular telephone subscriptions per 100 inhabitants $\left(b_{t}\right)$

$\begin{array}{cc}a_{t} / 60 & x^{*} 0.33 \\ b_{t} / R_{t} & x^{*} 0.33 \\ \log \left(c_{t}\right) / R_{t} & x^{*} 0.33\end{array}$

International Internet bandwidth (bit/s) per Internet user $\left(c_{t}\right)^{*}$

$\log \left(c_{t}\right) / R_{t} \quad x * 0.33$

ICT use (B)

Internet users per 100 inhabitants $\left(d_{t}\right)$

$\mathrm{d}_{\mathrm{t}} / 100 \quad \mathrm{x} * 0.5$

Fixed broadband Internet subscribers per 100 inhabitants $\left(e_{t}\right)$

$\mathrm{e}_{\mathrm{t}} / 60 \quad \mathrm{x} * 0.5$

ICT skills (C)

Secondary gross enrolment ratio $\left(f_{t}\right)$

$\mathrm{f}_{\mathrm{t}} / 100 \quad \mathrm{x}^{*} 0.5$

Tertiary gross enrolment ratio $\left(g_{t}\right)$

$\mathrm{g}_{\mathrm{t}} / 100 \quad \mathrm{x}^{*} 0.5$

Aggregated Index (IDI): $(A) * 0.4+(B) * 0.4+(C) * 0.2$

\begin{tabular}{|c|c|c|}
\hline Variable & Definition & Source \\
\hline $\begin{array}{l}\text { Fixed telephone } \\
\text { subscriptions per } \\
100 \text { inhabitants }\end{array}$ & $\begin{array}{l}\text { Fixed telephone subscriptions refers to the sum of active analogue } \\
\text { fixed telephone lines, voice-over-IP (VoIP) subscriptions, fixed wireless } \\
\text { local loop (WLL) subscriptions, ISDN voice-channel equivalents and } \\
\text { fixed public payphones. It includes all accesses over fixed infra- } \\
\text { structure supporting voice telephony using copper wire, voice services } \\
\text { using Internet Protocol (IP) delivered over fixed (wired)-broadband } \\
\text { infrastructure (e.g. DSL, fibre optic), and voice services provided over } \\
\text { coaxial-cable television networks (cable modem). It also includes fixed } \\
\text { wireless local loop (WLL) connections, which are defined as services } \\
\text { provided by licensed fixed-line telephone operators that provide last- } \\
\text { mile access to the subscriber using radio technology, when the call is } \\
\text { then routed over a fixed-line telephone network (and not a mobile } \\
\text { cellular network). }\end{array}$ & ITU \\
\hline $\begin{array}{l}\text { Mobile cellular } \\
\text { telephone } \\
\text { subscriptions per } \\
100 \text { inhabitants }\end{array}$ & $\begin{array}{l}\text { Mobile cellular telephone subscriptions refers to the number of } \\
\text { subscriptions to a public mobile telephone service which provides } \\
\text { access to the public switched telephone network (PSTN) using cellular } \\
\text { technology. It includes both the number of post-paid subscriptions } \\
\text { and the number of active prepaid accounts (i.e. that have been active } \\
\text { during the past three months). It includes all mobile cellular subscrip- } \\
\text { tions that offer voice communications. It excludes subscriptions via } \\
\text { data cards or USB modems, subscriptions to public mobile data } \\
\text { services, private trunked mobile radio, telepoint, radio paging and } \\
\text { telemetry services. }\end{array}$ & ITU \\
\hline $\begin{array}{l}\text { International } \\
\text { Internet } \\
\text { bandwidth }\end{array}$ & $\begin{array}{l}\text { International Internet bandwidth refers to the total used capacity of } \\
\text { international Internet bandwidth, in megabits per second (Mbit/s). } \\
\text { It is measured as the sum of used capacity of all Internet exchanges }\end{array}$ & ITU \\
\hline
\end{tabular}


Table 2. Continued

\begin{tabular}{l|l|l}
\hline Variable & Definition & Source \\
\hline $\begin{array}{l}\text { (bit/s) per } \\
\text { Internet user }\end{array}$ & $\begin{array}{l}\text { offering international bandwidth. If capacity is asymmetric, then the } \\
\text { incoming capacity is used. International Internet bandwidth (bit/s) per } \\
\text { Internet user is calculated by converting to bits per second and } \\
\text { dividing by the total number of Internet users. }\end{array}$ & \\
$\begin{array}{l}\text { \% age of } \\
\text { individuals using }\end{array}$ & $\begin{array}{l}\text { Individuals using the Internet refers to people who used the Internet } \\
\text { from any location and for any purpose, irrespective of the device and } \\
\text { network used. It can be via a computer (i.e. desktop computer, laptop } \\
\text { computer or tablet or similar handheld computer), mobile phone, } \\
\text { games machine, digital TV, etc.). Access can be via a fixed or mobile }\end{array}$ & ITU \\
$\begin{array}{l}\text { Fixed (wired)- } \\
\text { broadband } \\
\text { subscriptions per } \\
100 \text { inhabitants }\end{array}$ & $\begin{array}{l}\text { Fixed (wired)-broadband subscriptions refers to the number of } \\
\text { subscriptions for high-speed access to the public Internet (a TCP/IP } \\
\text { connection). High-speed access is defined as downstream speeds } \\
\text { equal to, or greater than, 256 kilobit per second (kbit/s). Fixed } \\
\text { (wired)-broadband includes cable modem, DSL, fibre and other fixed } \\
\text { (wired)-broadband technologies (such as Ethernet LAN, and } \\
\text { broadband-over-power line (BPL) communications). Subscriptions } \\
\text { with access to data communications (including the Internet) via } \\
\text { mobile-cellular networks are excluded. }\end{array}$ & ITU \\
$\begin{array}{l}\text { School } \\
\text { enrolment, } \\
\text { tertiary (\% gross) }\end{array}$ & $\begin{array}{l}\text { Gross enrolment ratio is the ratio of total enrolment, regardless of } \\
\text { age, to the population of the age group that officially corresponds to } \\
\text { the level of education shown. Secondary education completes the } \\
\text { provision of basic education that began at the primary level, and aims } \\
\text { at laying the foundations for lifelong learning and human develop- } \\
\text { ment, by offering more subject- or skill-oriented instruction using } \\
\text { more specialised teachers. }\end{array}$ & ITU \\
$\begin{array}{l}\text { Gross enrolment ratio is the ratio of total enrolment, regardless of } \\
\text { anrolment, } \\
\text { secondary } \\
\text { (\% gross) } \\
\text { condition of admission, the successful completion of education at the } \\
\text { secondary level. }\end{array}$ & ITU & \\
\hline
\end{tabular}

Notes: $\mathrm{R}=$ reference value, refer to Table $3, \mathrm{t}=$ year.

*To remove large number of outliers at the high end of the value scale, the data were first transformed to a logarithmic (log) scale.

Sources: ITC (2017), ITU (2009), ITU (2012), OECD (2017). 
Beng Ann Tee, Siew Yean Tham and Andrew Jia Yi Kam

Table 3. The reference value obtained through statistical procedures

\begin{tabular}{lrr}
\hline Reference value & b & c \\
\hline 2000 & 93.50 & 4.10 \\
2001 & 107.80 & 4.55 \\
2002 & 116.75 & 4.63 \\
2003 & 124.00 & 4.74 \\
2004 & 129.09 & 4.83 \\
2005 & 137.95 & 4.78 \\
2006 & 149.71 & 5.09 \\
2007 & 158.31 & 5.21 \\
2008 & 161.17 & 5.38 \\
2009 & 164.18 & 5.51 \\
2010 & 167.50 & 5.63 \\
2011 & 175.30 & 5.77 \\
\hline \multirow{2}{*}{ Notes: } & b: reference value for mobile cellular telephone subscriptions; \\
& c: reference value for international Internet bandwidth (bit/s). \\
& The reference value was computed by adding two standard deviations \\
& to the mean value of the indicator. & \\
Source: Computed by authors based on the method explained in ITU (2009).
\end{tabular}

\section{Regression Results}

Table 4 reports the estimation results for ASEAN-5's bilateral services exports. Depending on the Hausman test, they are estimated using either the random- or fixed-effects (RE or FE respectively). The countries of interest are Malaysia (M), Indonesia (I), Philippines $(P)$, Singapore $(S)$, Thailand $(T)$ and lastly the countries are aggregated together as ASEAN (A). Each country has four outputs denoted by numbers 1 to 4 , with each number representing the different ICT indicators used in the estimation model (respectively, IDI, ICT access, ICT use and ICT skills). For example, M1 in the model represents the Malaysian model estimated using IDI as the ICT proxy. M2 represents the Malaysian model with ICT access being used as the ICT proxy, and so forth. Each indicator enters the model separately, to avoid multicollinearity issues.

\subsection{Discussion of Findings}

Based on the standard gravity model, it is expected that bilateral services export increases with the size of both countries' GDP - a $1 \%$ increase in market size increases bilateral services export from 1 to approximately $1.5 \%$. Generally, service products do not have to be physically transported across locations. In other words, unless the nature of the service supplied requires the movement of physical persons, services products can be transmitted electronically. Therefore, the importance of distance in services trade may be low or even insignificant (Walsh, 2006). However, in the case of services exports which comprises mainly of tourism as for example in the case of Malaysia (55\% for total service exports in 2012), the impact of distance between the two trading 


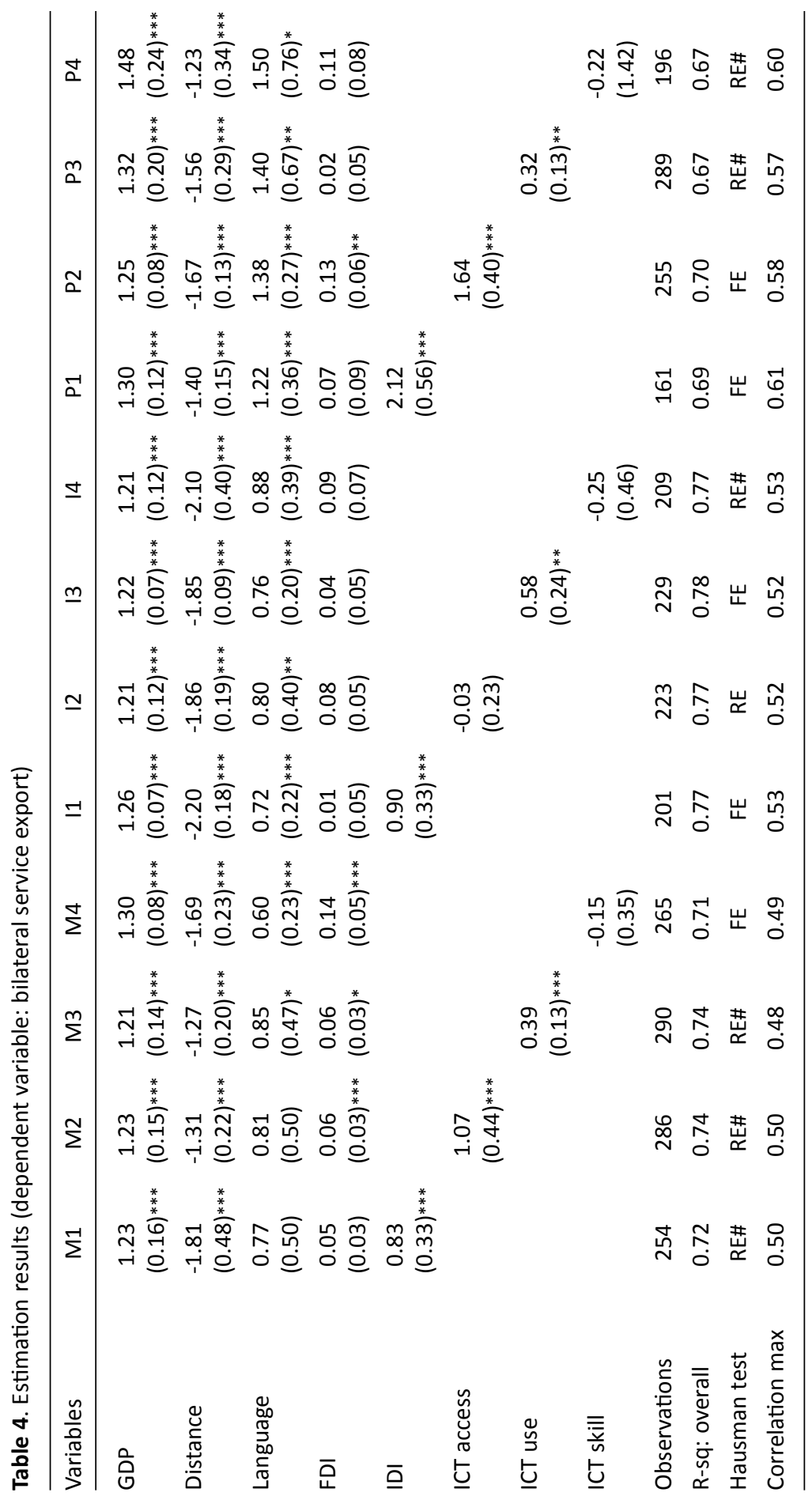




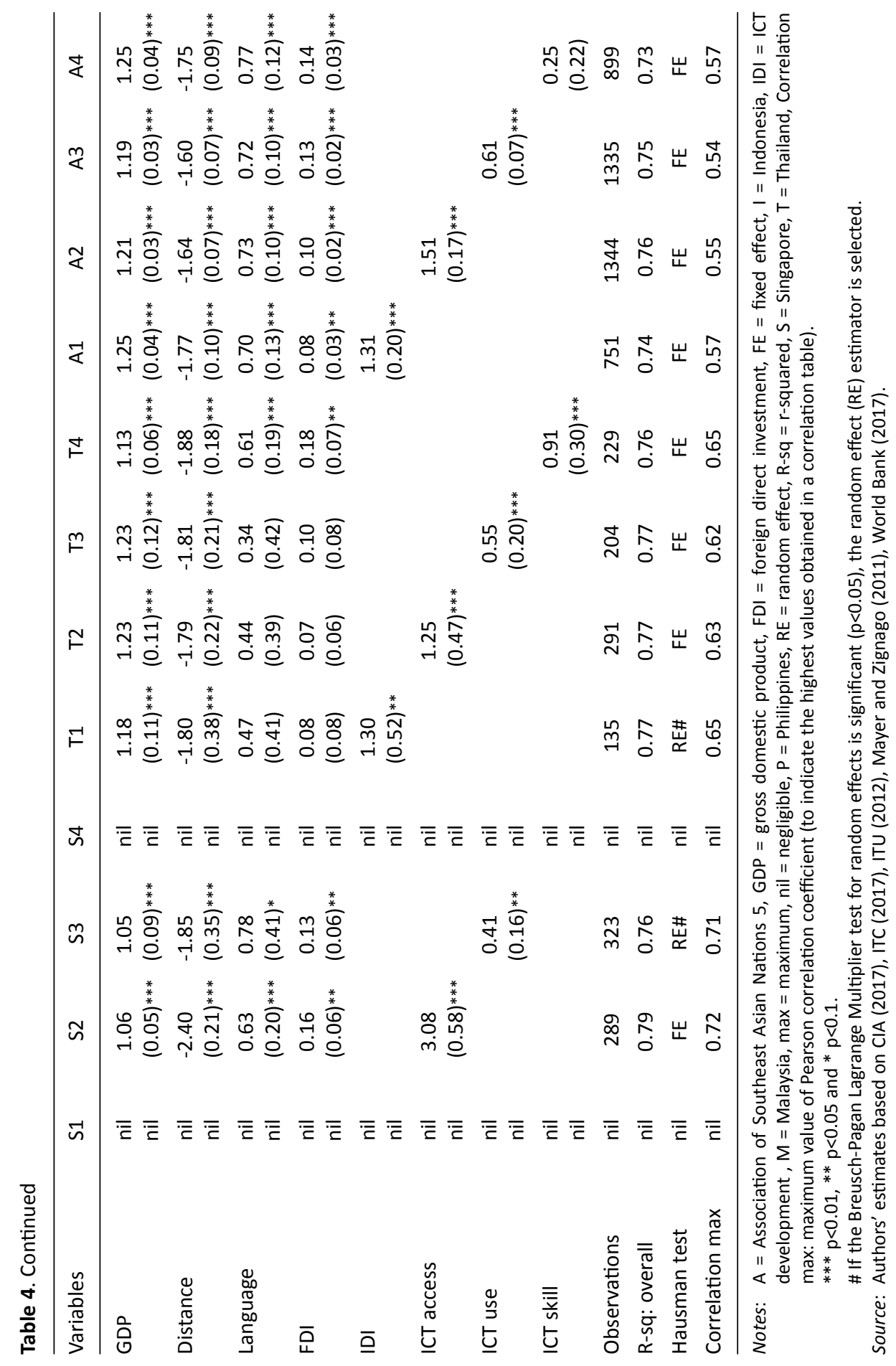


countries shows a negative relationship as tourism requires the physical movement of people. This implies services trade is expected to be lower when trade costs are high. The common language dummy has the expected positive and significant impact. This is because the use of a common language reduces the cost of communication (e.g., no need for additional translation costs for legal documents, marketing materials, etc.).

For the network effect, the variables are positive and significant. This is generally consistent with the findings of previous research (Choi, 2010; Lee, 2012; Mattes et al., 2012). The coefficients for the ICT (ranging from 0.32-3.08) are larger than the coefficients for the FDI (ranging from 0.06-0.16), implying that ICT has a stronger network effect on services export. Most of these coefficients are significant at the $1 \%$ level, meaning that the intensity of business networks and ICT development network facilitates export of services.

Our findings show that ICT indicators have a significant influence on service exports. The ICT sub-indices have a significant and positive network effect on most of the bilateral services exports. Table 4 shows that Thailand is the only country that has all the ICT sub-indices coefficients showing statistical significance. This is because the IDI index of Thailand is the highest in comparison to other ASEAN-5 countries (see Figure 1). ${ }^{9}$ ICT skills for Malaysia and Philippines, on the other hand, have yet to register an impact on the export services compared to the impact of ICT access and ICT use. This may due to the inability of the ICT skills level in both countries to reduce the sunk costs of trade.

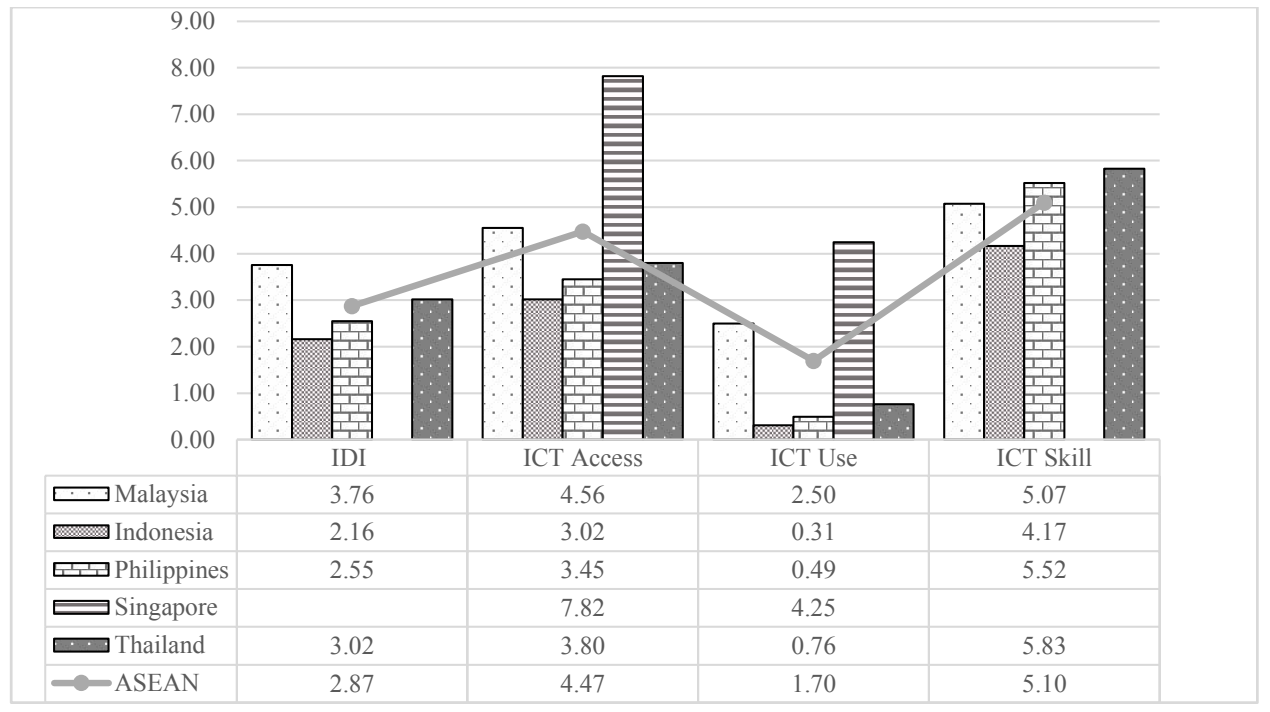

Figure 1. Average IDI and sub IDI for ASEAN 5, from 2000-2012

Note: ASEAN = Association of Southeast Asian Nations, IDI = ICT development index. Source: Authors' estimates based on ITU (2012) data.

9 As explained in the literature review, the influence from ICT will be more obvious for exporting countries with relatively high IDI or sub IDI values (Figure 1). 
However, for Indonesia, the overall impact of ICT network on the export services is less significant because it has the smallest number of significant ICT sub-indices that affect export services. The result suggests that this may be due to the differences in ICT level (in terms of access and skills) between Indonesia and its trading partners. With Indonesia's trading partners having a higher level of ICT use in comparison, Indonesia may need to upgrade its ICT use, which will increase the operation costs (namely, cost of upgrading its ICT level) for Indonesia when trading with its more ICT-oriented trade partners (Mattes et al., 2012).

In conclusion, the three components of the ICT indicator are considered closely related with each other, i.e., they are not mutually exclusive. For example, without ICT access, there will be no ICT use. Gaining access to ICT infrastructure is thus a prerequisite for ICT use. ICT skills on the other hand, are needed in order to make the best use of ICT (ITU, 2009). The higher the values of ICT indicators, the larger the impact of ICT has on the export of services. Therefore, our findings indicate that the aggregated IDI variable behave consistently with the expected signs.

A robustness test was also carried out using export of services data obtained from the OECD Trade in Value Added (TiVA) database (OECD, 2017). ${ }^{10}$ We found that $82.0 \%$ of the variables' coefficients received the same sign at similar significant levels in comparison to the results of this study. Among all the significant coefficients, $96.2 \%$ also indicated the same sign.

\section{Conclusion}

This paper seeks to examine the role of ICT in the ASEAN-5's services exports. Unlike previous research, the study contributes to the literature by examining several types of ICT network effect within the context of the ASEAN-5, where empirical work is limited by data. The estimation results using a one-way bilateral data set are encouraging, in that they provide strong support for the network effects of FDI and ICT on ASEAN-5's services exports. The findings also suggest that the network effect as proxied by ICT access, ICT use, and ICT capability can play an important role in increasing services exports. The network effect for ICT access is deemed more significant than ICT use and skills in affecting the exports of services. Therefore, the need to develop basic ICT facilities should be the main priority for ASEAN-5 countries in enhancing trade in services.

Trade costs, however, remain an impediment for services exports. To offset this cost, the development of a regional ICT initiative is crucial. The ASEAN-5 has already laid the foundation to accelerate the ASEAN Economic Community into the digital era. Existing initiatives such as the ASEAN Telecommunication Ministers flagship projects as well as additional initiatives under the ASEAN ICT Awards (AICTA) will continue to strengthen this foundation. The most crucial condition for exporting countries is to prioritise areas for regional cooperation and collaboration in ICT such as policy and regulatory enhancements, infrastructure development and digital inclusion. Since the findings suggest that the network effect is significant for exporting countries, ASEAN

10 The TiVA database was released for use to the public after the mirror data for this study was collected. Due to space constraints, the regression output is not presented but it is available upon request. 
will need to enhance regional cooperation in ICT development to facilitate services trade among the ASEAN member countries. For example, policies that aim to provide and improve ICT infrastructure can help to promote the export of services as well. Domestically, encouraging public institutions and firms to accelerate and increase their adoption of ICT usage is also desirable and should be encouraged with appropriate incentives. As shown in the results, ICT access has the highest impact on trade among the set of ICT indicators used. Therefore, this aspect of infrastructure should be given more attention in terms of its penetration rate to promote trade in services exports.

\section{References}

Abeliansky, A.L., \& Hilbert, M. (2017). Digital technology and international trade: Is it the quantity of subscriptions or the quality of data speed that matters? Telecommunications Policy, 41(1), 35-48. https://doi.org/10.1016/j.telpol.2016.11.001

Ahmed, E.M. (2007). ICT and human capital intensities impact on ASEAN5 productivity. The Journal of Knowledge Economy and Knowledge Management 2009, 4(1), 1-8.

Albuquerque, R., Loayza, N., \& Servén, L. (2005). World market integration through the lens of foreign direct investors. Journal of International Economics, 66(2), 267-295. https://doi. org/10.1016/j.jinteco.2004.07.002

Anderson, J.E. (1979). A theoretical foundation for the gravity equation. The American Economic Review, 69(1), 106-116.

Anderson, J.E., \& van Wincoop, E. (2003). Gravity with gravitas: A solution to the border puzzle. The American Economic Review, 93(1), 170-192. https://doi.org/10.1257/0002828033 21455214

Bankole, F.O., Brown, I., \& Osei-Bryson, K.-M. (2010, December). Does investments in ICT impact trade in Africa? A trend analysis of trade flows in Africa. Paper presented at Proceedings of SIG GlobDev Third Annual Workshop. Retrieved from http://aisel.aisnet.org/globdev2010/17

Central Intelligence Agency (CIA). (2017). The world factbook. Retrieved from https://www.cia. gov/library/publications/the-world-factbook/

Choi, C. (2010). The effect of the Internet on service trade. Economics Letters, 109(2), 102-104. https://doi.org/10.1016/j.econlet.2010.08.005

Christensson, P. (2010, January 4). ICT definition. Retrieved from https://techterms.com/ definition/ict

Dettmer, B. (2014). International service transactions: Is time a trade barrier in a connected world? International Economic Journal, 28(2), 225-254. https://doi.org/10.1080/10168737.2 013.825305

Farahani, T., \& Parvardeh, R. (2012). The impact of ICT on trade in Persian Gulf countries. Iranian Economic Review, 16(32), 63-73. https://doi.org/10.22059/IER.2012.32738

Freund, C., \& Weinhold, D. (2002). The Internet and international trade in services. American Economic Review, 92(2), 236-240. https://doi.org/10.1257/000282802320189320

Freund, C., \& Weinhold, D. (2004). The effect of the Internet on international trade. Journal of International Economics, 62(1), 171-189. https://doi.org/10.1016/S0022-1996(03)00059-X

Goswami, A.G., Gupta, P., Mattoo, A., \& Sáez, S. (2012). Service exports: Are the drivers different for developing countries? In Goswami, A.G., Mattoo, A., \& Sáez, S. (Eds.), Exporting services: A developing country perspective (pp. 25-79). Washington, D.C.: The World Bank. https://doi. org/10.1596/9780821388167_CHO2

Greaney, T.M. (2005). Measuring network effects on trade: Are Japanese affiliates distinctive? Journal of the Japanese and International Economies, 19(2), 194-214. https://doi.org/ 10.1016/j.jjie.2005.03.004 
Greaney, T.M. (2009). Measuring network effects on trade: A reexamination. Japan and the World Economy, 21(3), 219-225. https://doi.org/10.1016/j.japwor.2008.06.002

Grünfeld, L.A., \& Moxnes, A. (2003). The intangible globalization: Explaining the patterns of international trade in services (NUPI Discussion Paper No. 657). Oslo, Norway: Norwegian Institute of International Affairs. Retrieved from https://pdfs.semanticscholar.org/902c/ 5456775da15b6c84587d6d976686863770b6.pdf

Guermazi, B. (2007). Trade in information and communication services: Opportunities for East and Southern Africa (Final report on Kenya, Tanzania and Uganda). Washington, DC: World Bank Group. Retrieved from http://documents.worldbank.org/curated/en/116531468305685489/ Trade-in-information-and-communication-services-opportunities-for-East-and-SouthernAfrica

Helpman, E., Melitz, M., \& Rubinstein, Y. (2008). Estimating trade flows: Trading partners and trading volumes. The Quarterly Journal of Economics, 123(2), 441-487. https://doi. org/10.1162/qjec.2008.123.2.441

International Trade Centre (ITC). (2017). Trade Map: Trade statistics for international business development. Retrieved from http://www.trademap.org/index.aspx? ReturnUrl=\%2fCountry_ SelServiceCountry_TS.aspx

International Telecommunication Union (ITU). (2009). Measuring the information society: The ICT development index. Geneva, Switzerland: Author.

International Telecommunication Union (ITU). (2012). World telecommunication/ICT indicators database. Geneva, Switzerland: Author.

International Telecommunication Union (ITU). (2016). Measuring the information society report. Geneva, Switzerland: Author. Retrieved from https://www.itu.int/en/ITU-D/Statistics/ Documents/publications/misr2016/MISR2016-w4.pdf

Katz, M.L., \& Shapiro, C. (1985). Network externalities, competition, and compatibility. The American Economic Review, 75(3), 424-440.

Kimura, F., \& Lee, H-H. (2006). The gravity equation in international trade in services. Review of World Economics, 142(1), 92-121. https://doi.org/10.1007/s10290-006-0058-8

Kotnik, P., \& Hagsten, E. (2013). ICT as enabler of exports. Retrieved from http://www.frbatlanta. org/documents/news/conferences/13caed/e_2_kotnik.pdf

Kurihara, Y., \& Fukushima, A. (2013). Impact of the prevailing Internet on international trade in Asia. Journal of Sustainable Development Studies, 3(1), 1-13.

Lee, J. (2012). Network effects on international trade. Economics Letters, 116(2), 199-201. https:// doi.org/10.1016/j.econlet.2012.02.017

Lendle, A., Olarreaga, M., Schropp, S., \& Vézina, P.-L. (2016). There goes gravity: EBay and the death of distance. The Economic Journal, 126(591), 406-441. https://doi.org/10.1111/ ecoj.12286

Lennon, C. (2009). Trade in services and trade in goods: Differences and complementarities (The Vienna Institute for International Economic Studies Working Paper, 53), wiiw.

Lennon, C., Mirza, D., \& Nicoletti, G. (2009). Complementarity of inputs across countries in services trade. Annals of Economics and Statistics, 93/94, 183-205. https://doi.org/10.2307/ 27917388

Liu, Y. (2011). An empirical investigation of ICT and international trade (Master's thesis, Jiangsu University, Jiangsu, People's Republic of China). Retrieved from http://cdmd.cnki.com.cn/ Article/CDMD-10299-1012261575.htm

Mattes, A., Meinen, P., \& Pavel, F. (2012). Goods follow bytes: The impact of ICT on EU trade (German Institute for Economic Research Discussion Paper 1182). Berlin: DIW Berlin. Retrieved from http://kolegia.sgh.waw.pl/pl/KGS/struktura/IGS-KGS/struktura/KBGPAW/ oferta/Documents/11_MATTES.pdf 
Mayer, T., \& Zignago, S. (2011). Notes on CEPII's distances measures: The GeoDist Database (CEPII Working Paper 2011-25). Retrieved from http://www.cepii.fr/CEPII/en/bdd_modele/ presentation. $a s p ? i d=6$

Michael, T.D. (2011). Determinants of trade in services in Africa: A gravity model approach (Master's thesis, Addis Ababa University, Addis Ababa, Ethiopia). Retrieved from http:// 213.55.95.56/bitstream/handle/123456789/14225/Michael\%20Tedla.pdf?sequence= 1 \&isAllowed $=y$

Nath, H.K., \& Liu, L. (2016). Information and communications technology (ICT) and services trade (Department of Economics and International Business Working Paper No. 16-01). Huntsville, Texas: Sam Houston State University. Retrieved from https://www.shsu.edu/academics/ economics-and-international-business/documents/wp_series/wp16-01_paper.pdf

Organization for Economic Co-operation and Development (OECD). (2017). Trade in Value Added (TiVA). [Data file]. Retrieved from https://stats.oecd.org/index.aspx?queryid=75537

Shemayev, V. (2014). An alloy of steel and information and communication technology (ICT): Does it facilitate trade? (Doctoral dissertation, The University of Montana Missoula, Missoula, MT). Retrieved from https://www.researchgate.net/publication/280385583_An_Alloy_of_ Steel_and_Information_Communication_Technology_ICT_Does_It_Facilitate_Trad

Sinkovics, N., Sinkovics, R.R., \& "Bryan" Jean, R. (2013). The Internet as an alternative path to internationalization? International Marketing Review, 30(2), 130-155. https://doi.org/ $10.1108 / 02651331311314556$

Song, X. (2008). Demonstration about the effect of ICT on the service trade (Master's thesis, Beijing University of Posts and Telecommunications, Beijing, China). Retrieved from http:// cdmd.cnki.com.cn/Article/CDMD-10013-2008138808.htm

Tinbergen, J.J. (1962). Shaping the world economy: Suggestions for an international economic policy. New York, NY: The Twentieth Century Fund.

United Nations Conference on Trade and Development (UNCTAD). (2008). Measuring the impact of ICT use in business: The case of manufacturing in Thailand. Geneva, Switzerland: Author.

United Nations Conference on Trade and Development (UNCTAD). (2011). Information economy report 2011. Geneva, Switzerland: Author.

Van der Marel, E. (2012). Determinants of comparative advantage in services (Forschungsschwerpunkt Internationale Wirtschaft Working Paper No. 87). Vienna, Austria: FIW. Retrieved from https://www.econstor.eu/handle/10419/121086

Walsh, K. (2006). Trade in services: does gravity hold? A gravity model approach to estimating barriers to services trade (The University of Dublin, Institute for International Integration Studies (IIIS) Discussion Paper 183). Dublin, Ireland: IIIS. Retrieved from http://citeseerx.ist. psu.edu/viewdoc/download?doi=10.1.1.521.6025\&rep=rep1\&type=pdf

Weitzel, T., Wendt, O., von Westarp, F.G., \& Konig, W. (2003). Network effects and diffusion theory: Network analysis in economics. International Journal of IT Standards and Standardization Research, 1(2), 1-21. https://doi.org/10.4018/jitsr.2003070101

World Bank. (2009). Malaysia - Productivity and investment climate assessment update. Washington, D.C.: Author.

World Bank. (2017). World Development Indicators 2017. Washington, D.C.: Author. Retrieved from http://databank.worldbank.org/data/reports.aspx?source=world-developmentindicators

World Trade Organization (WTO). (2017). Time series on international trade. Geneva, Switzerland: Author. Retrieved from https://www.wto-ilibrary.org/trade-monitoring/trade-profiles2019_27b474b7-en

Yushkova, E. (2014). Impact of ICT on trade in different technology groups: Analysis and implications. International Economics and Economic Policy, 11(1-2), 165-177. https://doi. org/10.1007/s10368-013-0264-5 
